\title{
INSTITUTIONAL AND ECONOMIC DETERMINANTS OF FDI: A COMPARARISON BETWEEN THE EUROPEAN UNION AND THE MENA REGION
}

\author{
Aurora Galego and José Manuel Caetano
}

\begin{abstract}
FDI flows to the MENA region have been relatively low when compared to neighboring countries. This paper aims at investigating whether there are significant region-specific factors for FDI performance in MENA and EU regions. We employ a panel data approach and use the inward FDI performance index as dependent variable, including both institutional and macroeconomic variables as FDI determinants. The results reveal similar impact of the economic factors but significant differences between the two regions on some institutional determinants, in particular in what concerns the investment climate, government size and trade barriers. This leads to the conclusion that more appropriate policies are needed in the MENA region in order to develop a friendly economic and institutional environment to attract foreign investors.
\end{abstract}

KEYWORDS: Foreign Direct Investment, determinants, Institutions, Middle East North Africa countries (MENA), European Union (EU), Panel Data

Author Notes: The authors would like to thank the helpful comments and suggestions of an anonymous referee. The authors also gratefully acknowledge the partial financial support of the Fundação para a Ciência e a Tecnologia (FCT), Programa Operacional "Ciência, Tecnologia, Inovação" (POCTI). 